\title{
Alternative Knowledge and the Right to Food and Nutrition Watch
}

This editorial introduces the 2016 issue of The Right to Food and Nutrition Watch, dedicated this year to Keeping Seeds in Peoples' Hands ${ }^{1}$ as a construction of local, alternative knowledge that strives to contribute to the development of food policy and governance at diverse local, national, regional and global scales. This year's peer-reviewed publication focuses on seeds, land and other natural resources through thematic essays and ten supportive national and regional reports from peasant and indigenous communities that have developed and preserved seeds for millennia. These populations, and especially the traditional female seed gatherers among them, are finding their human rights to save, use, exchange and sell seeds overshadowed and even criminalized by private and intellectual property regimes.

\section{Alternative knowledge and human rights}

The Right to Food and Nutrition Watch is published by three public interest civil society organizations: Bread for the World, FIAN International and Interchurch Organisation for Development Cooperation (ICCO Cooperation). The Watch first appeared in 2008 when the reference to 'rights' necessarily inferred human rights. This period marked the height of a disastrous round of global agricultural market speculation and the related world food crisis. A hotly debated contest ensued at the time over the development of an improved global food governance system ${ }^{2}$. While this battle is ongoing, a critical outcome was the 2009 reform of the largely inactive Committee on World Food Security (CFS), established in 1974 at the United Nations Food and Agriculture Organization (FAO). The CFS vision 'strive [s] for a world free from hunger where countries implement the voluntary guidelines for the progressive realization of the right to adequate food in the context of national food security. ${ }^{3}$ The human rights based framework approach of the 2005 Voluntary Guidelines for the Right to Food Guidelines ${ }^{4}$ presses for broad and inclusive participation of rights holders in monitoring public state action. Additionally, the CFS broke new ground by institutionalizing a participant role for civil society and other non-state actors in policy development ${ }^{5}$.

Peer review of The Watch is orchestrated by a small editorial board of civil society members and a few academics and is coordinated by the Watch Consortium, a group of 24 civil society organizations belonging to the Global Network for the Right to Food and Nutrition. Peer review is conducted through the assessment of civil society colleagues, associates and contemporaries with an eye toward bolstering marginalized voices and experiences into the realm of the trends and paradigms of the human right to food and nutrition. Watch reviews are rarely blind. Themes are selected and authors invited with the intention of sharpening contemporary policy debates with the benefit of 'on-the-ground' voices. Textual criticisms are addressed in teams. The objective is the inclusion of narratives and analysis that reveal lived realities that expose the invisible. As Ángel Strapazzón writes,

It is our words that forge, create, invent, disarm and organize. Those who wish to hear: listen. Those who wish to see: look. We have learnt from our teachers - the wise men and women from the mountains, rivers, seas, forest and gorges - that our words walk, and lead, our words forge and touch yet touch and forge: our words create (Strapazzón, p. 30-31 ${ }^{6}$ ).

Who can produce the science that underpins sustainable approaches to agriculture and food production? Academics are trained to omit the passionate, to transfigure it into forms that inevitably alienate Strapazzón's teachers. Merriam Webster describes science as: '(a) knowledge about or study of the natural world based on facts learned through experiments and observation; (b) a particular area of scientific study (such as biology, physics or chemistry): a particular branch of science; (c) a subject that is formally studied in a college, university, etc. ${ }^{7}$ This technocratic characterization eclipses social science, the study of people and culture, and it ensconces the wondrous and diverse manifestations of epistemology within the narrow confines of the academy which is, advantages notwithstanding, beholden to state and corporate largesse and legitimated through the scrutiny of our own in-bred group of academic peers.

Revelations of passionate knowledge that expose the realities of the most marginalized achieves at least three critical outcomes. Firstly, it moves nation states toward the progressive realization of their human rights treaty obligations to prioritize the demands of the marginalized $^{8}$. Secondly, it accomplishes a Paulo Freire kind of pedagogy ${ }^{9}$ wherein the power, origin and recognition of knowledge production shifts toward those perceived to need education and benign charity, making conventional producers of knowledge (perhaps especially in academia) uncomfortable and often threatened. Thirdly, formal acknowledgement of alternative knowledges leverages marginalized groups into the messy participatory processes of democratic spaces, further alarming diverse existing elites. 
Peasants, indigenous groups, and public-interest civil society house, protect and create knowledge systems, including 'science', beyond the narrow framework of Merriam Webster. Alternative knowledges are foundational to holding states accountable to their obligations to realize the human right to adequate food and nutrition progressively, inclusively, and with emphasis on those most marginalized ${ }^{10}$. A human rights-based analysis of a progressively realized human right, e.g., the right to save seeds, is measured therefore not (only) in terms, for example, like how many seed varieties are saved from year to year (an outcome measure), but also whether and how most marginalized seed savers can integrate themselves into public policy on seeds, agriculture and people's food and nutrition security (a process measure; Anderson $^{11}$, p. 15).

The critical relevance of including local knowledge in analysis and action is recognized beyond human rightsbased approaches. 'Business as usual is not an option' states the International Assessment of Agricultural Knowledge, Science and Technology for Development (IAASTD; McIntyre et al.) $)^{12}$. The 6-year project initiated by the World Bank and the FAO drew on the work of over 400 experts from all regions of the world and found that massive investments in agricultural science co-existed with shocking and persistent conditions of hunger, poverty, food insecurity, malnutrition in over- and undernourished populations and ongoing degradation of the environment. The IAASTD called for participatory policy making and informed advocacy by underrepresented stakeholders in agricultural development, most particularly the food producers themselves, to address the eight themes that surfaced: local knowledge and community-based innovation, the role of women in agriculture, human health, the need for improved natural resource management, trade and markets, the diversion of farmland for food to bioenergy production, biotechnology and climate change. With this call, the IAASTD challenged epistemological tradition by calling for the peer participation of food producers in the construction of a science relevant to peoples' survival and well-being.

Efforts to insert local and alternative knowledges into global food governance mechanisms are under assault. An example is the cooptation of 'rights' language through the obfuscation of its foundation in the 1948 Universal Declaration on Human Rights and its realignment as property rights. In his essay on 'Privatization and Corporate Capture of Global Fisheries Policy', Mads Barbesgaard demonstrates how academic conferences and publications such as the edited volume on Rights Based Fishing move this agenda forward, 'where the "rights-based" proponents no longer speak openly of privatization as they did in 1989, but instead use "strategically benign rhetoric" that masks the actual aims, not to mention consequences, of the "rights-based" approach. ${ }^{, 13}$ Karine Eliane Peschard echoes this 'disturbing shift in language...' wherein farmers' human rights to seeds 'are increasingly couched as "privileges" and "exceptions" "... and subordinated to the dominant property rights of seed breeders ${ }^{14}$ [italics added].

\section{Keeping Seeds in Peoples' Hands}

The 2016 Watch focuses on seeds and the lands on which they are propagated as the nexus of a largely women's cultural practice that empowers both community sovereignty and self-determination, as well as ecological survival. Monsalve et al. claim that seeds and agrobiodiversity represent the neglected backbone of the human right to food and nutrition.

Biodiversity embodies a dynamic, constantly changing, and fluid patchwork of relations between people, plants, animals, other organisms, and the environment. Thus, biodiversity is the manifestation of the creativity and knowledge of peasants as they engage with the natural environment to satisfy their needs, while striving for autonomy ${ }^{15}$.

Sovereignty over the reproduction of human and nonhuman life depends upon women's rights and the secure tenure of land and water. Seeds cannot be owned and traded as commodities; they are the fruits and fuel of labor. While this seems idyllically absurd to some, it radically disturbs others to an extent leading to the criminalization $^{16}$, harassment and even assassination of peasants' rights advocates. This 2016 Watch issue is dedicated to women and men around the world risking their lives to defend peoples' sovereignty and human rights, especially Berta Cáceres, Lenca indigenous leader, environmental activist, and co-founder and coordinator of the Civic Council of Popular and Indigenous Organizations of Honduras who was murdered in March 2016 fighting against a hydroelectric dam that would have destroyed the lands and traditional communal properties of her people.

The evolutive principal of human rights asserts their non-static nature and the necessary progressive development of our understanding and implementation of them. To that end, work is required and ongoing to secure institutional linkages between the human right to adequate food and nutrition and peasants' rights to seeds, agricultural biodiversity and secure land tenure. The former UN Special Rapporteur on the Right to Food, Olivier De Schutter, brought attention to states' obligation 'both to preserve and enhance informal and traditional farmers' seed systems as well as to regulate commercial seed systems.' ${ }^{17}$ This observation highlights contradictions within global seed (and other modes of wild foods gathering, fisheries and livestock food production) governance mechanisms. On the one hand, the 1991 Act of the International Union for the Protection of New Varieties of Plants (UPOV Convention) protects the intellectual property rights (IPR) that buoy the Green Revolution's agricultural policies, trade agreements, and the genetically modified organisms (GMOs) that 
undergird them. On the other hand, Sofia Monsalve Suárez et al. describe the evolving frameworks dedicated to formalizing the intersection of peasants' rights and the human right to adequate food and nutrition, including:

- The 1999 General Comment on the Right to Adequate Food states that 'food availability' within the core of the human right to food and nutrition refers to the capacity to feed oneself directly from productive land or other natural resources, implying that seeds and seed access, as well as land and water are indispensable (paragraph 12).

- The 2004 FAO Voluntary Guidelines to Support the Progressive Realization of the Right to Adequate Food in the Context of National Food Security (Right to Food Guidelines) articulates the relationship between the right to food and nutrition, seeds, and agricultural biodiversity (Guidelines 8D), although not farmers' rights to seeds.

- The 2009 FAO International Treaty on Plant Genetic Resources for Food and Agriculture reflects upon farmers' rights (Article 9) and specifically protects their rights to save, use, exchange, and sell farm-saved seed (Article 9.3).

- The 2012 CFS Voluntary Guidelines on the Responsible Governance of Tenure of Land, Fisheries and Forests support traditional seed saving, sharing, and re-using through the strategy of secure land tenure to protect the spaces of seed propagation.

- The draft Declaration on the Rights of Peasants and Other People Working in Rural Areas ${ }^{18}$ wherein draft Articles 22-23 concern Rights to Seeds and Traditional Agricultural Knowledge and Practice.

Powerful transnational seed purveyors depend upon the general public's faith in intellectual property rights as the regulatory tool that safeguards the world's food supply and very survival. The unevenly pitched battle against this corporate interference with traditional seed saving systems is waged with careful scrutiny of available information and the public heralding of 'quiet' knowledges and local food organization and governance ${ }^{19}$. For example, Mamadou Goita et al. refute the presumed importance of transnational markets for world food and nutrition security.

Around $70 \%$ of the food consumed in the world is produced by smallholder producers and workers. Most of it is channeled through local, national and regional markets. Only $10-12 \%$ of agricultural products is traded on the international market .... The idea of 'connecting smallholders to markets' is misleading: globally more than $80 \%$ of smallholders operate in domestic markets, which are the most important for food security and nutrition ${ }^{20}$.

As in the case of the 2016 Keeping Seeds in Peoples' Hands, half of each Watch is dedicated to regionally balanced reports linked to the individual volume theme. A small sampling of the present issue includes Elfrieda Pschorn-Strauss' essay on how women's traditional seed saving and intergenerational knowledge transfer work, that boosts their self-determination as well as their communities' food sovereignty, is imperiled by the contemporary effort to expand the green revolution into Africa ${ }^{21}$. Taleb Brahim portrays how the four decade long displacement of Sahrawis in Western Sahara and associated difficulties in adapting to unfamiliar environments and ecosystems required that they secure land and learn anew how to self-produce adequate and nutritious food to supplement the mainly dry cereals, pulses, sugar and oil distributed by relief agen$\operatorname{cies}^{22}$. Surrounded by sugar cane and grain monoculture on the traditional lands from which they were displaced, Valéria Burity et al. describe how the Guarani and Kaiowá peoples face desperate levels of food insecurity and are pleading violations of human rights, including the human right to food and nutrition, in their case of land theft against the Brazilian State now registered with the Inter-American Commission on Human Rights $^{23}$. Laura Gutiérrez Escobar and Germán Vélez launch five country case studies in Central and South America to illustrate how GMOs under UPOV protection complicate and interfere with food aid and development in rural areas; they update readers on the development of related pro-IPR national laws such as the successful Biosafety Law (Law 11.105/2005) in Brazil and the derogated Law on the Protection of New Varieties of Plans in Guatemala ${ }^{24}$. After criticizing the city of Detroit in the United States for the lack of a comprehensive food policy in 2006, Malik Yakini explains how the Black Community Food Security Network, a group dedicated to building community power and self-reliance through strategies such as urban agriculture, youth development and cooperative economics, was appointed to create a task force that led to the 2009 opening of the Detroit Food Policy Council, which designates six of the 21 public seats to grassroots community residents ${ }^{25}$. At an historical moment of cautious optimism for national democratic governance in Myanmar, Jennifer Franco and Khu $\mathrm{Khu} \mathrm{Ju}$ introduce how a right to land movement (Land in Our Hands, LIOH, or 'Doe Myay' in Burmese) is using the Land Tenure Guidelines to demonstrate where and how the government violated peasant land use, including through military backed land confiscation that has not respected ethnic and customary land tenure rights such as shifting cultivation and water and forest commons ${ }^{26}$.

The 2016 Watch is part of a growing movement to centralize local knowledge and marginalized experience within the science of the world around us and to democratize public policies on food governance with it. That trend may require of us in academia, as elsewhere, to 
reappraise our elite seats at tables of knowledge, analysis, and policy and move over, make way, incorporate and collaborate.

\section{References}

1. Right to Food and Nutrition Watch. 2016. The previous two issues are "People's Nutrition is Not a Business" (2015) and "Ten Years of the Right to Food Guidelines: Gains, Concerns and Struggles" (2014). Available at Web site http://www.righttofoodandnutrition.org/watch (verified 10 November 2016).

2. Valente, F.L.S. and Suarez-Franco, A.M. 2010. Human rights and the struggle against hunger: Laws, institutions, and instruments in the fight to realize the right to adequate food. Yale Human Rights \& Development Law Journal 13 (2):435-461.

3. Committee on Food Security (CFS). 2009. Reform of the Committee on World Food Security, Final version. CFS:2009/2 Rev.2. para., 4, p. 2. Available at Web site http:// www.fao.org/fileadmin/templates/cfs/Docs0910/ReformDoc/ CFS_2009_2_Rev_2_E_K7197.pdf (verified 10 November 2016).

4. Food and Agriculture Organization. 2005. Voluntary guidelines to support the progressive realization of the right to food in the context of national food security. Available at Web site http://www.fao.org/docrep/meeting/009/y9825e/ y9825e00.htm (verified 10 November 2016).

5. CFS op cit. at 3. pp. 4-7. See also: Committee on World Food Security. 2010. Proposal for an International Food Security and Nutrition Civil Society Mechanism for Relations with CFS. Available at Web site http://www.fao. org/docrep/meeting/019/k8933e.pdf (verified 10 November 2016).

6. Strapazzón, Á. 2016. Towards an assessment of the implementation of the guidelines on tenure of land, fisheries and forests: A tool for social movements' struggles. In $o p$ cit. at 1, p. $29-31$.

7. Merriam-Webster Online Dictionary. Available at Web site http://www.merriam-webster.com/dictionary/science (verified 10 November 2016).

8. See for example, Bellows, A.C., Núñez Burbano de Lara, M. D., and Viana, R.dS.G. The evolving nature of the human rights system and the development of the right to adequate food and nutrition concept. In A.C. Bellows, F.S.L. Valente, S. Lemke, and M.D. Núñez Burbano de Lara (eds). Gender, Nutrition, and the Human Right to Adequate Food: Toward an inclusive Framework. Routledge. p. 1-57.

9. Freire, P. 1970. Pedagogy of the Oppressed. Bloomsbury.

10. Bellows, A.C., Valente, F.S.L., Lemke, S., and Núñez Burbano de Lara, M.D. (eds). 2016. Gender, Nutrition, and the Human Right to Adequate Food: Toward an inclusive Framework. Routledge.
11. Anderson, M. 2016. Moving toward people-centered monitoring of the right to food and nutrition. In op cit. at 1, p. 14-16: 15 .

12. McIntyre, B.D., Herren, H.R., Wakhungu, J., and Watson, R.T. (eds). 2009. Agriculture at a Crossroads. International Assessment of Agricultural Knowledge, Science and Technology for Development. Synthesis Report: A synthesis of the Global and Sub-Global IAASTD Reports. Island Press. p. 3.

13. Barbesgaard, M. 2016. Privatization and corporate capture of global fisheries policy. In op cit. at 1, p. 34-35:36.

14. Peschard, K.E. 2016. Farmers' rights to seed: conflicts in international legal regimes. In op cit. at 1, p. 22-23; 23.

15. Monsalve Suárez, S., Rahmanian, M., and Onorati, A. 2016. Seeds and agricultural biodiversity: The neglected backbone of the right to food and nutrition. In op cit. at 1, p. 18-22; 21.

16. Ibid. p. 19.

17. Ibid. at p. 20; note 13. De Schutter, O. 2009. The Right to Food. Seed policies and the right to food: enhancing agrobiodiversity and encouraging innovation. para. 7. Available at Web site http://www.srfood.org/images/stories/pdf/official reports/20091021_report-ga64_seed-policies-and-the-right-tofood_en.pdf (verified 10 November 2016).

18. Human Rights Council. 2013. Declaration on the Rights of Peasants and Other People Working in Rural Areas [draft]. Available at Web site http://www.ohchr.org/Documents/ HRBodies/HRCouncil/WGPleasants/A-HRC-WG-15-1-2_ En.pdf. (verified 10 November 2016).

19. Forster, T. and Mattheisen, E. 2016. Territorial food systems: Protecting the rural and localizing human rights accountability. In op cit. at 1, p. 38-41.

20. Goita, M., McKeon, N., and Sall, N. 2016. Peoples' markets or corporate supply systems? Negotiating in the Committee on World Food Security. In op cit. at 1, p. 41-43: 41-42. With reference to FAO and IIED reports, see footnotes $17 \& 18$.

21. Pschorn-Strauss, E. 2016. African food sovereignty: Valuing women and the seed they keep. In op cit. at 1, p. 49-51.

22. Brahim, T. 2016. Cultivating hope for Western Sahara: Moving my people toward self-sufficiency. In op cit. at 1, p. 55-56.

23. Burity, V., Machado, F., and Cupsinski, A. 2016. The Great Guarani and Kaiowá peoples and their struggle for rights and food life in Brazil. In op cit. at 1, p. 65-67.

24. Gutiérrez Escobar, L. and Vélez, G. 2016. The struggle for peoples' free seeds in Latin America: Experiences from Brazil, Ecuador, Colombia, Honduras, and Guatemala. In op cit. at 1, p. 68-71.

25. Yakini, M. 2016. From the bottom up: Building the Detroit Food Policy Council. In op cit. at 1, p. 43-44.

26. Franco, J. and Ju, K.K. 2016. Land and peace in Myanmar: Two sides of the same coin. In op cit. at 1, p. 62-64.

Anne C. Bellows

Syracuse University, Syracuse, New York, USA *Corresponding author: acbellow@syr.edu 